\title{
INTEGRATED METHOD OF EXTRACTION, FORMALIZATION AND AGGREGATION OF COMPETITIVE AGENTS EXPERT EVALUATIONS IN A GROUP
}

Context. The problem of extraction, formalization and aggregation of expert evaluations performed during selection of the best solution from possible alternatives set was considered. The problem actuality is defined by different application areas, additional analysis necessity and group evaluation under uncertainty.

Objective. The research objective was to raise quality of the decisions made by group of experts due to increase of individual expert evaluation process efficiency and improvement of evaluation aggregation process.

Method. The integrated method which consists of individual and group evaluation was proposed for the problem solution.

The modified method of extraction and formalization of individual expert evaluations which is based on the analytic hierarchy process modification and includes absolute and relative evaluation phases was proposed. It evaluates expert competence based on confidence coefficient for expert judgments.

The modified method of agent group evaluation based on summation of individual expert evaluations of every alternative was proposed. It makes total evaluation based on relative quantitative importance of the agents and confidence coefficients for judgments of every group participant. It gives preference to judgments of qualified experts to increase solution quality.

Results. The experimental investigation of the proposed methods confirmed availability of the developed mathematical support. The proposed methods are able to detect and control nontrivial issues in tasks which are solved.

Conclusions. Scientific novelty of the paper consists in the proposed integrated method of extraction, formalization and aggregation of expert evaluations in group which enables to define integrated assessment of competitive agents as well as to evaluate confidence coefficient for expert judgments directly during individual evaluation process and to use it in the following group decision-making phase.

Practical significance of the paper results consists in the developed information technology which made it possible to put the method into practice for solving of the tender support tasks and experiment results.

Keywords: expert evaluation, group evaluations, individual evaluations, expert competence, competitive agents.

\section{NOMENCLATURE}

$A$-pairwise comparison matrix which elements are criteria or agents;

$A g$ - set of competitive agents;

$a_{r p}$ - result of comparison of the $r$ object with the $p$ object according to general criterion;

$B$ - pairwise comparison matrix of competitive agents according to criteria;

$b_{i j}$ - evaluation of the $i$-th agent according to the $j$-th criterion;

$C$ - criterion set;

$D$ - set of competitive agents evaluations;

$d_{\text {best }}$ - agent which is considered most preferable;

$d_{i}$ - part of the $i$-th agent in the total estimate;

$f_{l}$ - function which extracts element with the largest key value;

$f_{2}$ - functional dependence;

$g w_{g}-$ global priority vector for the $g$-th expert;

$g w_{g}^{\text {best }}$ - agent which is considered most preferable by the $g$-th expert;

$g w_{g i}$ - element of global priority vector which corresponds to the evaluation of the $i$-th agent by the $g$-th expert;

$K A$ - number of compared elements (criteria or agents);

$K M$ - number of evaluation criteria;

$K N$ - number of agents;
$K S$ - number of experts;

$\mathrm{PCM}$ - pairwise comparison matrix;

$Q$ - set of "control" questions;

$q_{k}$ - comparative evaluation of random agent pair from the $k$ matrix;

$S$ - set of experts;

$s_{g}-$ the $g$-th expert from the set $S$;

Sum $_{i}$ - total evaluation of the $i$-th competitive agent;

$v_{g}$ - confidence coefficient for judgments of the expert $s_{g}$;

$v_{g}(k)$ - confidence coefficient for judgment of the $g$-th expert on the $k$-th question;

$W$ - local priority vector;

$w_{r}$ - the $r$-th element of local priority vector $W$.

\section{INTRODUCTION}

The problems of selection of one solution from the set of possible variants are known in different activity areas. These problems are often characterized by the fact that the choice has significant impact on problem-solving environment state. At the same time most commonly it isn't possible to select the best solution from the set of alternatives in such problems without additional analysis of all possible variants as well as factors which impact on solution quality.

As factors which are evaluation criteria can be not only quantitative but also qualitative, and evaluation is executed under uncertainty, automatic decision-making isn't possible. 
Hence expert knowledge are used for selection of the best variant from the set of alternatives.

To raise objectivity of evaluation procedure it should be done by more than one expert. However one part of experts in group may turn out to be more competent than others in the problem which is solved, so judgments of this part of expert group should be preferred during aggregation of group evaluation.

So the development of integrated method which enables to extract and aggregate expert evaluations taking into account competence of every expert is actual.

Object of the research is process of formalization and aggregation of expert evaluations. Subject of the research is methods of evaluation performed during selection of solutions from the set of alternatives (which are considered as competitive agents).

The research objective is to raise quality of the decisions made by group of experts due to increase of individual expert evaluation process efficiency and improvement of evaluation aggregation process.

The following tasks were defined to achieve the research objective:

- improvement of the method of extraction and formalization of expert judgments;

- development of the method of expert competence evaluation during individual evaluation process;

- improvement of the method of group evaluation based on individual expert evaluations taking into account expert competence;

- practical investigation of the proposed methods efficiency using the developed information technology.

\section{PROBLEM STATEMENT}

Suppose we have the set $A g$ of competitive agents, the set $S$ of experts who can estimate these agents and the set $C$ of the evaluation criteria.

Then the problem of competitive agents selection is to define estimates $D=\left\{d_{i} \mid i=1, \ldots, K N\right\}$ of each agent from the set $A g$ using transformation $i=f_{1}\left(A g_{j}\right), j=1 . . K N$, which executes descending ordering according to the values of $d_{i}$.

Values of elements from the set $D$ are defined by the dependence $D=f_{2}(C, S)$. Method of determination of the dependence should be proposed in the paper for competitive agents selection problem solving.

It should be noted that the given problem includes also competitive agent selection problem which consists in selection of competitive agent with the biggest part in total evaluation $d_{\text {best }}=\max _{i} d_{i}$.

\section{REVIEW OF THE LITERATURE}

When decision is made by expert group, collaboration using open dynamic discussion has substantial disadvantages which can impact on decision, making it subjective [1-4]. Therefore in some circumstances it is more efficient to question experts individually, permitting them to use only personal experience making judgments [5-6]. At the same time expert should be proposed to place all possible solutions in descending order of its correspondence to the task as well as to estimate solutions quantitatively determining this correspondence level or relative priority of each alternative comparing it with another one. To obtain such estimations there is a lot of traditional methods: the Schulze method [7], the method of preference [8], the analytic hierarchy process [9], fuzzy methods and the COPRAS method [10]. But the described methods have substantial disadvantages which are critical for the problem which is solved. So the Schulze method and the method of preference make evaluations only by one criterion and limit scale of correspondence to the task by natural numbers. The analytic hierarchy process is sufficiently laborious and doesn't enable to take into account correspondence level of considered variants to the problem objective. Fuzzy methods may be unefficient for practical tasks, because these methods can make inaccuracy for similar alternative evaluations during transformation of triangular numbers to real ones. The COPRAS method solves tasks of multicriterion alternatives evaluation based on its correspondence to the task objective, but this method doesn't enable to detect its priorities comparing with each other. The methods [11-19] enable to make evaluations according to several criteria based on association rules synthesis [11], decision trees [12], radial basis neural networks [13], production rules [14], neuro-fuzzy networks [15], cascade systems [16] and sequential $[11,17]$ or parallel $[18,19]$ computing. However these methods are applicable only when training data samples, which contain collected information about objects and processes under consideration, are available, that makes difficult and in some circumstances eliminates possibility of its applicability for solving of tasks which need expert evaluation.

As analysis result it should be noted that regarding the problem which is considered decomposition approach of the analytic hierarchy process enables to develop the most appropriate problem model [20], since experts can use quantitative and qualitative criteria for evaluation of agents using qualitative criteria based on clear scale.

Thus disadvantages of existing expert evaluation methods cause necessity of improvement of methods which conduct individual evaluation of competitive agents by expert group and further evaluations aggregation taking into account competency of every expert.

\section{MATERIALS AND METHODS}

Currently only one approach is usually used for extraction and formalization of expert judgments at a time. Possible approaches include the following ones: expert can estimate agent as consistent entity based on its correspondence to the given problem or expert can compare all agents with each other creating relative rating. Both these approaches give only one-track evaluation. For integrated evaluation of alternatives as competitive agents within the scope of the current problem it was proposed to make evaluation using two approaches [21-22]:

- absolute evaluation as determination of competitive agents correspondence to the customization demands for each criterion;

- relative evaluation based on comparison of agents with each other according to each criterion.

At the beginning of the proposed method of extraction and formalization of individual expert evaluations level of 
correspondence of competitive agents to the problem statement according to each criterion is evaluated (absolute evaluation). This phase is made by absolute percentage evaluation (from 0 to $100 \%$ ) of each agent according to each criterion comparing to the problem statement requirements. After evaluation obtained values has to be normalized using division by 100 . The result of this stage is the matrix $B$ of the size $K N \mathrm{x} K M$ which consists of evaluations $b_{i j} \in[0,1]$ for $i=1, \ldots, K N, j=1, \ldots, K M$ :

$$
B=\left(\begin{array}{cccc}
b_{11} & b_{12} & \ldots & b_{1 K M} \\
b_{21} & b_{22} & \ldots & b_{2 K M} \\
\ldots & \ldots & \ldots & \ldots \\
b_{K N 1} & b_{K N 2} & \ldots & b_{K N K M}
\end{array}\right) .
$$

Then the modified analytic hierarchy process is used to evaluate agents comparatively according to each criterion (relative evaluation).

Relative evaluation process is generally represented on activity diagram (fig. 1).
The method of paired comparisons [9] is used to compare criteria according to the given task and to compare agents according to criteria. According to this method pairwise comparison matrices (PCM) are obtained from the results of comparison of every row element with every column element.

So the matrix $A$ of size $K A \times K A$ is obtained from elements $a_{r p}$ which are presented by real numbers:

$$
A=\left(\begin{array}{cccc}
1 & a_{12} & \ldots & a_{1 K A} \\
a_{21} & 1 & \ldots & a_{2 K A} \\
\ldots & \ldots & \ldots & \ldots \\
a_{K A 1} & a_{K A 2} & \ldots & 1
\end{array}\right) .
$$

Every expert that takes part in the evaluation process has to compare all elements with each other presenting evaluations as numeric values in accordance with fundamental ratio scale [23] and has to complete corresponding PCM.

One of the main disadvantages of the method of paired comparisons is its laboriousness. It is necessary to analyze fundamental properties of PCM [9] to reduce the number of comparison operations which have to be executed by expert.

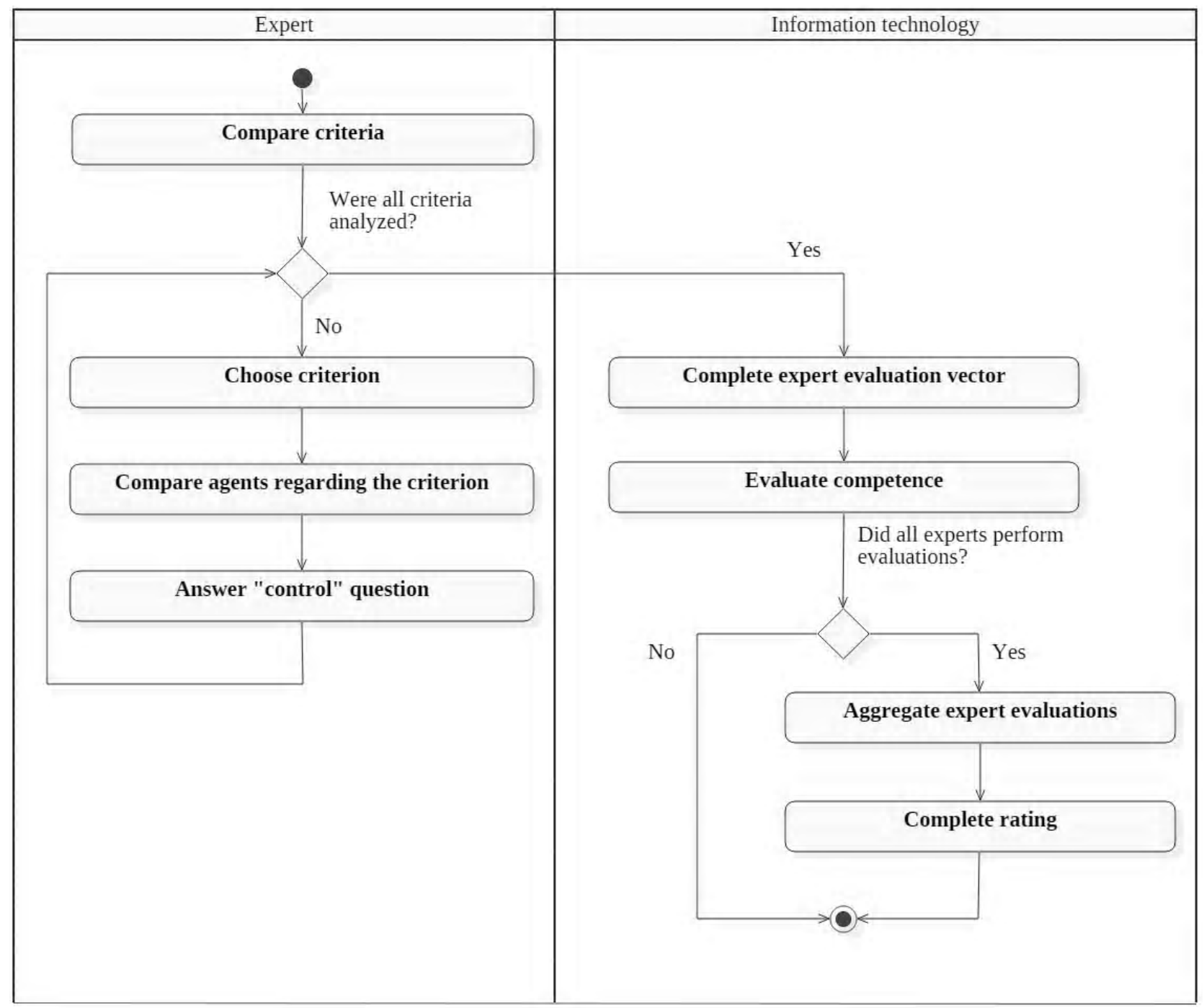

Figure 1 - Activity diagram for relative agent evaluation (UML 2.5 notation) 
The main property of PCM is the following: for each $r$, $p=1, \ldots, K A$ elements $a_{r p}>0$. Besides that under $r=p \quad a_{r p}=1$, because these elements present comparisons of each element with oneself and have to correspond to equal significance.

The third property is inverse symmetry of the matrix about the main diagonal. For each $r, p=1, \ldots, K A a_{p r}=1 / a_{r p}$, so expert has to complete only evaluations which are situated above the main diagonal.

Thus the PCM $A$ will take the following form:

$$
A=\left(\begin{array}{cccc}
1 & a_{12} & \ldots & a_{1 K A} \\
1 / a_{12} & 1 & \ldots & a_{2 K A} \\
\ldots & \ldots & \ldots & \ldots \\
1 / a_{1 K A} & 1 / a_{1 K A} & \ldots & 1
\end{array}\right) .
$$

The phase of PCM filling has to be done for every hierarchy level.

The results of this phase are PCMs where criteria of the same hierarchy level are compared with each other, criteria of lower hierarchy level are compared with each other according to criteria of higher hierarchy level, if there are ones, and agents are compared with each other according to criteria.

Then local priority vectors are obtained from the collection of PCMs. Local priority vector $W=\left(w_{1}, w_{2}, \ldots, w_{K A}\right)^{T}$ has to be determined for every obtained PCM. The main property of the obtained local priority vectors is that sum of vector components equals 1 , that is $\sum_{r=1}^{K A} w_{r}=1$.

To obtain global priority vector $g w_{g}=\left\{g w_{g 1}, g w_{g 2}, \ldots, g w_{g K N}\right\}$ for each $g$-th expert, local priorities of each evaluated agent are multiplied by priority of the corresponding criterion and results are added to each other.

Then the corresponding values of the global priority $g w_{g i}$ of every agent are compared with each other. Agent which is considered most preferable by the g-th expert will have the biggest value of the global priority:

$$
g w_{g}^{\text {best }}=\max _{i} g w_{g i}, i=1, \ldots, K N .
$$

The tasks which are solved in the context of the considered problem are seldom completely identical, because every task has its own features and differences: for example technical or time constraints. Application of the analytic hierarchy process demands familiarity with these features, constraints and its influence on the final result from experts. However it isn't always possible because of the wide specialization of experts who take part in questioning in practice.

In this case it is necessary to evaluate additionally expert competence and confidence in decisions made by him [24]. Expert competence level should be then used for aggregation of group evaluation [25].
Confidence coefficient $v_{g}$ corresponds to quantification of the level of confidence in competence of expert $s_{g} \in S$ $(g=1, \ldots, K S)$ in the presented problem.

It is proposed to add set of «control» questions $Q$ to pairwise comparison sequence to evaluate confidence coefficients for expert judgments. Each element of the set $Q$ is defined as $q_{k}=a_{r p}(r \in\{2, K N\}, p \in\{1, K N-r\})$ which is comparative evaluation of random pair of agents from the bottom part of the $k$-th PCM where agents are compared according to criteria. So the set $Q$ is defined in the following form:

$$
Q=\left\{q_{k} \mid k=1, \ldots, K M\right\} .
$$

«Control» question is a question which was restated and repeated to expert. Such questions enable to determine confidence of expert answering main questions in agents evaluation process.

Since all elements of the matrix $A$ are inverse symmetrical that is for each $r, p=1, \ldots, K A a_{p r}=1 / a_{r p}$, it is possible to verify if expert judgments which were gotten comparing random pair of agents are equal to expert judgments which were gotten during primary comparisons. This verification is based on evaluation of PCM elements which are situated under the main diagonal as inverse proportion to the values of elements which are situated in the matrix part which was filled by expert.

For each $k$-th PCM random pair of agents $p$ and $r$ is selected from the elements of the matrix which are situated under the main diagonal and is proposed to expert for comparison.

If values $a_{r p}$ and $a_{p r}$ are bigger or lower than 1 at the same time, then confidence coefficient for the given question should be specified as $v_{g}(k)=0$ (the $g$-th expert showed his incompetence answering the $k$-th question). Otherwise confidence coefficient for the given question should be calculated using the following expression:

$$
v_{g}(k)=\left\{\begin{array}{l}
1-\frac{\left|a_{r p}-1 / a_{p r}\right|}{\max \left(a_{r p}, 1 / a_{p r}\right)},\left(a_{r p} \geq 1\right) \cap\left(a_{p r} \leq 1\right), \\
1-\frac{\left|a_{p r}-1 / a_{r p}\right|}{\max \left(a_{p r}, 1 / a_{r p}\right)},\left(a_{r p}<1\right) \cap\left(a_{p r}>1\right) .
\end{array}\right.
$$

Overall confidence coefficient $v_{g}$ for judgments of the expert $s_{g}$ is calculated using the following formula:

$$
v_{g}=\frac{\sum_{k=1}^{K M} v_{g}(k)}{K M} .
$$

After questioning is finished, final value of $v_{g}$ should be evaluated. If $v_{g}=1$ expert should be considered as competent and his judgments can be trusted. If $v_{g}=0$ expert should be considered as incompetent relatively to the 
solved task. In this case evaluations of this expert should not be taken into account in aggregation of group evaluation.

After all experts of the group made own evaluations, global priority vector $g w_{g}$ and confidence coefficient for expert judgments $v_{g}$ are defined for each expert from number $K S$, the method of group agent evaluation has to be executed. This method calculates total evaluation $\mathrm{Sum}_{i}$ for each $i$-th agent based on summation of evaluations $g w_{g i}$ which were given to the agent by the $g$-th expert. At the same time evaluations has to be multiplied by confidence coefficients for expert judgments:

$$
\operatorname{Sum}_{i}=\sum_{g=1}^{K S} v_{g} \cdot g w_{g i} .
$$

Thus the bigger value confidence coefficient $v_{g}$ for expert judgments has, more impact $g$-th expert will have on overall evaluation.

After summation is done, overall rating of competitive agents $D$ is defined. Each individual evaluation is multiplied by confidence coefficient for expert judgments and part $d_{i}$ of each $i$-th agent in the total evaluation is calculated using the following formula:

$$
d_{i}=\frac{\operatorname{Sum}_{i}}{\sum_{i=1}^{K N} \operatorname{Sum}_{i}}, \sum_{i=1}^{K N} d_{i}=1 .
$$

Agents are ordered by decrease of $d_{i}$ values, in that way defining function $f_{1}$ which can be implemented as binary heap. The result of this operation is agent rating, where agent which is considered most preferable by expert group heads the list. Based on the obtained rating responsible person makes final decision on the best agent. In most cases it is agent which is the first in the list and it becomes solution of the competitive agents selection problem.

\section{EXPERIMENTS}

The proposed methods were used for the development of the competitive agents selection information technology.
The tasks of competitive agents selection were solved for experimental investigation of practical availability of the proposed methods using the developed information technology.

The investigation was made based on data collected from tender tasks, participant offers and tender results accumulated by design companies LLC "SK Inzhenernye systemy" and "VST" (Ukraine) and evaluations of experts who were selected and invited based on the tender tasks.

The following competitive agents (companies) were considered in the task of tender for design, supply and mounting of metalware and barriers:

- AO "Metallist SMK", Kharkiv;

- Atlas Word (Germany), branch in Kyiv;

- Borga Hale, Gdynia, Poland.

The following competitive agents were considered in the task of supply of materials and equipment for mounting of shopping center buildings:

- Master Profi, Dnipro;

- Remko, Kyiv;

- Atlas Word, Kyiv;

- Askon, Kamyanske;

- IBT, Kyiv.

Design companies traditionally used pricing appraisal or oral discussion method for evaluation during tender process. However since tender results can be determined in long time horizon [26] it is necessary from one to six months after tender is ended for its efficiency evaluation. During experimental investigation the results of traditional approach were compared with the results obtained by the proposed integrated method.

\section{RESULTS}

Solving the task of tender for design, supply and mounting of metalware and barriers the derived proposals were formalized as competitive agents and were proposed to the group of three experts for evaluation. Expert evaluations were used for agents rating aggregation.

The rating of competitive agents obtained by the traditional approach (without taking into account confidence coefficient for expert judgments) can be summarized in the following list (fig. 2a):

- Borga Hale - 35,60\%;

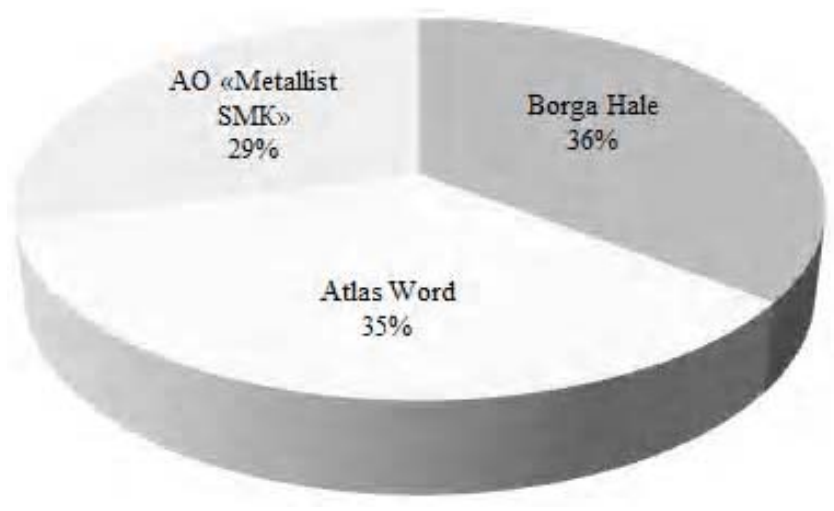

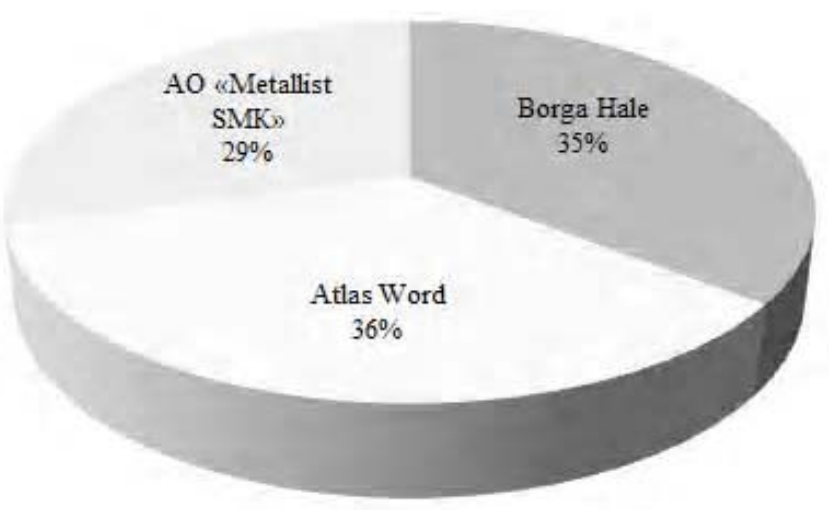

b

Figure 2 - The results of competitive agents evaluation in the task of tender for design, supply and mounting of metalware and barriers: a - without taking into account confidence coefficient for expert judgments; $\mathrm{b}$ - taking into account confidence coefficient for expert judgments 
- Atlas Word - 35,35\%;

- AO "Metallist SMK" - 29,05\%.

The rating of competitive agents obtained using the modified methods (taking into account confidence coefficient for expert judgments) can be summarized in the following list (fig. 2b):

- Atlas Word - 35,60\%;

- Borga Hale - 35,50\%;

- AO "Metallist SMK" - 28,9\%.

Solving the task of supply of materials and equipment for mounting of shopping center buildings the derived proposals were formalized as competitive agents and were proposed to the group of four experts for evaluation.

Before the beginning of evaluation process experts were proposed to examine tender task using the developed information technology. Then traditional approach based on oral discussion was used for evaluation. Based on oral discussion and simple voting methods expert commission elected the tender offer of "Master Profi" because of its minimum cost and delivery time.

Then agents evaluation was repeated by the same expert commission using competitive agents information technology based on the proposed methods (fig. 3).
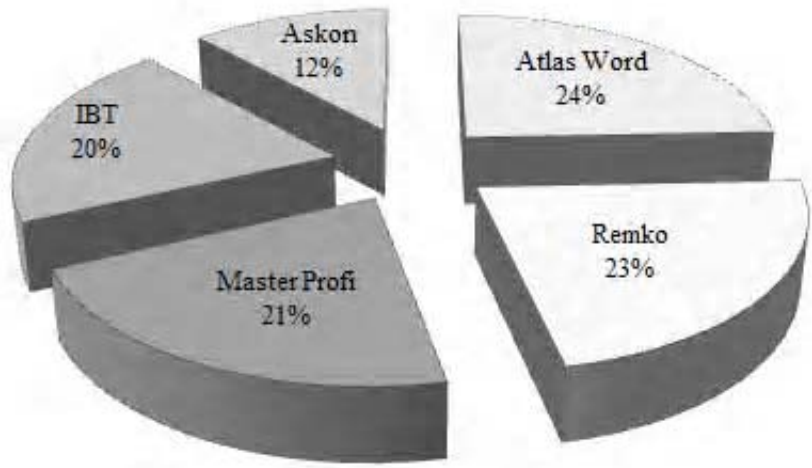

Figure 3 - The results of competitive agents evaluation in the task of supply of materials and equipment for mounting of shopping center buildings taking into account confidence coefficient for expert judgments
Besides that individual expert preferences and confidence coefficients for expert judgments were defined (fig. 4).

The rating of competitive agents obtained using the integrated method and taking into account confidence coefficient for expert judgments can be summarized in the following list:

- Atlas Word - 24.35\%;

- Remko-22.40\%;

- Master Profi - 21.31\%;

- IBT - 20.13\%;

- Askon - 11.81\%.

\section{DISCUSSION}

Results of competitive agents evaluation in the task of tender for design, supply and mounting of metalware and barriers showed that taking into account confidence coefficient for expert judgments changed positions of participants in rating. It should be noted that the bigger the dispersion of confidence coefficients for expert judgments is, more impact experts with bigger values of confidence coefficient will have on tender results.

As the result of the proposed integrated method application to the tender for supply of materials and equipment for mounting of shopping center buildings the tender offer of the company «Master Profi» which was chosen during oral discussion occupied only the third place in the rating. It is caused by its failures which were missed during basic analysis: delayed starting date of execution phase and small production volume regarding competitors.

Thus investigation results confirm availability of the developed competitive agents selection information technology in whole and the proposed integrated method particularly for practical tasks solving since the proposed problem solution helps to detect nontrivial problems and failures of the considered competitive agents.

Analysis of the obtained results showed that the proposed integrated method of extraction, formalization and aggregation of expert evaluations enabled to raise accuracy

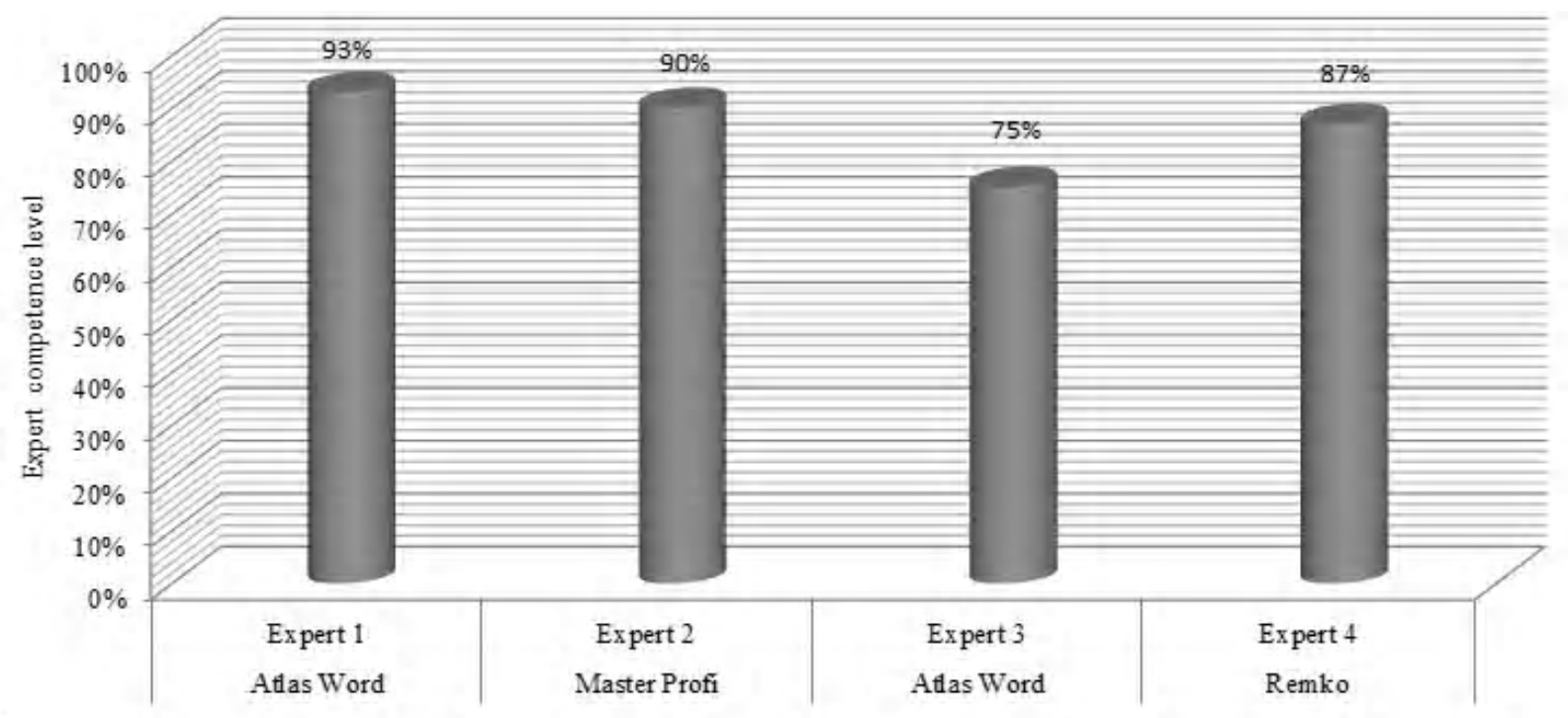

Figure 4 - Expert competence level 
of group evaluations due to formalization of individual evaluations derivation process as well as implementation of expert competence evaluation mechanism. In turn it ensures group decision making process efficiency and enables to raise quality of the final solution.

The proposed integrated method can be used for practical expert evaluation tasks solving in many areas of industry, economics and medicine: tender processes in all areas of state and business activity, complicated clinical decision support, expert evaluation of techware quality in industry.

In what follows it is planned to investigate availability of the developed method for solving of practical tasks in other activity areas and the dependence of the method efficiency on application domain.

\section{CONCLUSIONS}

In this paper actual problem of competitive agents selection was solved based on group expert evaluations.

Scientific novelty of the paper consists in the proposed integrated method of extraction, formalization and aggregation of expert evaluations in group which enables to define integrated assessment of competitive agents as well as to evaluate confidence coefficient for expert judgments directly during individual evaluation process and to use it in the following group decision-making phase. The proposed method gives preference to judgments of competent experts in the overall evaluation, at the same time increasing quality of the decision.

Practical significance of the paper results consists in the developed information technology and experiment results. Information technology implemented the proposed integrated method that made it possible to put the method into practice for solving of the tender support tasks. Experiments confirmed availability of the developed mathematical support and made it possible to recommend it for practical application.

Application of the proposed mathematical support and the developed information technology for other practical tasks directly concerned with competitive agents evaluation should be noted as further research directions.

\section{ACKNOWLEDGEMENTS}

The research was made in the context of the state budget research and development project "Methods and tools of computational intelligence and parallel computing for big data processing in diagnostic systems" (state registration number 0116U007419) of Zaporizhzhya National Technical University with the support of the international project "Centers of Excellence for young RESearchers" of the Tempus programme of the European Union (registration number 544137-TEMPUS-1-2013-1-SK-TEMPUS-JPHES).

\section{REFERENCES}

1. Карнышев А. Д. Психология деятельности и управления : учеб. пособие / А. Д. Карнышев, Е. А. Иванова. - Иркутск : ИГЭА, 2001. - $186 \mathrm{c}$.

2. Мулен Э. Кооперативное принятие решений : аксиомы и модели / Э. Мулен. - М. : Мир, 1991. - 464 с.

3. Майерс Д. Социальная психология / Д. Майерс. - СПб. : Питер, 2013. - 800 с.
4. Ambrusa A. How individual preferences are aggregated in groups: An experimental study / A. Ambrusa, B. Greinerb, P. A. Pathakc // Journal of Public Economics. - 2015. - Volume 129. - P. 1-13.

5. Budziński R. Model of competence of experts in the computer decision support system / R. Budziński, J. Becker // Quantitative Methods In Economics. - 2013. - Volume XIV, Issue 1. - Pp. 53-64.

6. Patel H. T. A Study on the Effectiveness of Group Activity and Group Discussion Method in English / H. T. Patel // International Journal of Research in Humanities and Social Sciences. - 2014. Volume 2, Issue 1. - P. 13-15.

7. Parkes D. C. A Complexity-of-Strategic-Behavior Comparison between Schulze's Rule and Ranked Pairs / D. C. Parkes, L. Xia / / Proceedings of the Twenty-Sixth AAAI Conference on Artificial Intelligence. - 2012. - P. 1429-1435.

8. Roszkowska E. Rank ordering criteria weighting methods - a comparative overview / E. Roszkowska // Optimum. Studia Ekonomiczne. - 2013. - № 5 (65). - P. 14-33.

9. Saaty T. L. Models, Methods, Concepts \& Applications of the Analytic Hierarchy Process / T. L. Saaty, L. G. Vargas. - Springer US, 2012. $-346 \mathrm{p}$.

10. An Integrated Approach of Fuzzy Linguistic Preference Based AHP and Fuzzy COPRAS for Machine Tool Evaluation / [H. T. Nguyen, S. Z. M. Dawal, Y. Nukman at al.] // PLOS One. - 2015. № 10 (9). -24 p.

11. Oliinyk A. Training Sample Reduction Based on Association Rules for Neuro-Fuzzy Networks Synthesis / A. Oliinyk, T. Zaiko, S. Subbotin // Optical Memory and Neural Networks (Information Optics). - 2014. - Vol. 23, № 2. - P. 89-95.

12. Oliinyk A. The decision tree construction based on a stochastic search for the neuro-fuzzy network synthesis / A. Oliinyk, S. A. Subbotin // Optical Memory and Neural Networks (Information Optics). - 2015. - Vol. 24, № 1. - P. 18-27.

13. Subbotin S. A. The method of diagnostic model synthesis based on radial basis neural networks with the support of generalization properties / S. A. Subbotin // Radio Electronics. Computer Science. Control. - 2016. - № 2. - P. 64-69.

14. Oliinyk A. Production rules extraction based on negative selection / A. Oliinyk // Radio Electronics, Computer Science, Control. 2016. - № 1. - P. 40-49.

15. Oliinyk A.O. Experimental Investigation with Analyzing the Training Method Complexity of Neuro-Fuzzy Networks Based on Parallel Random Search / A. O. Oliinyk, S. Yu. Skrupsky, S. A. Subbotin // Automatic Control and Computer Sciences. 2015. - Vol. 49, Issue 1. - P. 11-20.

16. Bodyanskiy Ye. V. An evolving cascade system based on neurofuzzy nodes / Ye. V. Bodyanskiy, O. K. Tyshchenko, O. O. Boiko // Radio Electronics. Computer Science. Control. - 2016. - № 2. P. $40-45$.

17. Oliinyk A. Association Rules Extraction for Pattern Recognition / A. Oliinyk, S.A. Subbotin // Pattern Recognition and Image Analysis. - 2016. - Vol. 26, № 2. - P. 419-426.

18. Oliinyk A. O. Using Parallel Random Search to Train Fuzzy Neural Networks / A. O. Oliinyk, S. Yu. Skrupsky, S. A. Subbotin // Automatic Control and Computer Sciences. - 2014. - Vol. 48, Issue 6. - P. 313-323.

19. Subbotin S. Individual prediction of the hypertensive patient condition based on computational intelligence / S. Subbotin, A. Oliinyk, S. Skrupsky // Information and Digital Technologies: International Conference IDT'2015, Zilina, 7-9 July 2015: proceedings of the conference. - Zilina: Institute of Electrical and Electronics Engineers, 2015. - P. 336-344.

20. Pangeran M. H. Conceptual model of analytical network process for prioritizing risk in a PPP infrastructure project / M. H. Pangeran, K. S. Pribad // Proceedings of the First Makassar International Conference on Civil Engineering, March 9-10, 2010. - P. 1217-1227. 
21. Jao C. S. Efficient Decision Support Systems - Practice and Challenges in Multidisciplinary Domains / Chiang S. Jao. - InTech, 2011. -478 p.

22. Rush C. Expert Judgement in Cost Estimating: Modelling the Reasoning Process / Christopher Rush, Rajkumar Roy. Concurrent Engineering. - 2001. - № 9. - P. 271-284.

23. Андрейчиков А. В. Анализ, синтез, планирование решений в экономике / А. В. Андрейчиков, О. Н. Андрейчикова. - М. : Финансы и статистика, 2002. - 368 с

24. Shrotriya S. Prediction of the Winner by Using a Weighted Approach of Preferential Balloting Systems on the Basis of Their Satisfied Criterions and Artifice Behavioral Complexity /

S. Shrotriya, A. Pandey // 3rd International Conference on Information Security and Artificial Intelligence (ISAI 2012), Singapore. - 2012. - P. 142-146.

25. Wang B. Determining decision makers' weights in group ranking: a granular computing method / B. Wang, J. Liang, Y. Qian // International Journal of Machine Learning and Cybernetics. 2015. - Volume 6, Issue 3. - P. 511-521.

26. Tao L. Decision Support for Contractor Selection: Incorporating consolidated Past Performance Information / Lijuan Tao. University of Hong Kong. $-2010 .-184$ p.

Article was submitted 14.12.2016. After revision 29.12.2016.

Колпакова Т. О. ${ }^{1}$, Олійник А. О. ${ }^{2}$, Льовкін В. М. ${ }^{3}$

${ }^{1}$ Ст. викладач кафедри програмних засобів Запорізького національного технічного університету, Запоріжжя, Україна

${ }^{2}$ Канд. техн. наук, доцент, доцент кафедри програмних засобів Запорізького національного технічного університету, Запоріжжя, Україна

${ }^{3}$ Канд. техн. наук, доцент кафедри програмних засобів Запорізького національного технічного університету, Запоріжжя, Україна КОМПЛЕКСНИЙ МЕТОД ВИДОБУВАННЯ, ФОРМАЛІЗАЦІЇ ТА АГРЕГАЦЇ̈ ЕКСПЕРТНИХ ОЦІНОК КОНКУРУЮЧИХ АГЕНТІВ У ГРУПI

Актуальність. Розглянуто проблему видобування, формалізації та агрегації експертних оцінок під час пошуку найкращого рішення з множини можливих. Актуальність даної проблеми визначається різноманіттям галузей застосування, необхідністю додаткового аналізу та груповим оцінюванням за умов невизначеності.

Мета. Мета даного дослідження полягала в підвищенні якості рішень, що приймаються групою експертів, за рахунок підвищення ефективності процесу отримання індивідуальних експертних оцінок та вдосконалення процесу їх подальшої агрегації.

Метод. Запропоновано комплексний метод, що складається з індивідуального та групового оцінювання, для розв'язання даної проблеми.

Удосконалено метод видобування та формалізації індивідуальних експертних оцінок. Запропонований метод грунтується на модифікації методу аналізу ієрархій, містить етапи абсолютного та відносного оцінювання, дозволяє визначити компетентність експерта шляхом обчислення коефіцієнта довіри до його суджень.

Удосконалено метод визначення групових оцінок агентів на основі підсумовування індивідуальних експертних оцінок за кожним рішенням. Даний метод враховує під час обчислення сумарної оцінки кількісну перевагу агентів один над одним та коефіцієнти довіри до суджень кожного учасника групи. Це дозволяє вважати судження компетентних експертів більш значущими з метою підвищення якості отримуваного рішення.

Результати. Проведене експериментальне дослідження підтверджує працездатність розробленого математичного забезпечення. Розроблені методи продемонстрували здатність визначати і усувати неочевидні проблеми в задачах, що розв'язуються.

Висновки. Наукова новизна роботи полягає в тому, що запропоновано комплексний метод видобування, формалізації та агрегації експертних оцінок у групі, який дозволяє визначати комплексну оцінку конкуруючих агентів, а також обчислювати кількісне значення коефіцієнту довіри до суджень експерта безпосередньо в процесі отримання індивідуальної оцінки і в подальшому використовувати ііі для прийняття групових рішень.

Практична значимість результатів роботи полягає в тому, що розроблено інформаційну технологію, яка реалізує запропонований комплексний метод, що дозволило застосувати на практиці даний метод для розв'язання задачі проведення тендерів, та проведено експерименти.

Ключові слова: експертне оцінювання, групові оцінки, індивідуальні оцінки, компетентність експертів, конкуруючі агенти.

Колпакова Т. А. ${ }^{1}$, Олейник А. А. ${ }^{2}$, Левкин В. Н. ${ }^{3}$

${ }^{1}$ Ст. преподаватель кафедры программных средств Запорожского национального технического университета, Запорожье, Украина

${ }^{2}$ Канд. техн. наук, доцент, доцент кафедры программных средств Запорожского национального технического университета, Запорожье, Украина

${ }^{3}$ Канд. техн. наук, доцент кафедры программных средств Запорожского национального технического университета, Запорожье, Украина

КОМПЛЕКСНЫЙ МЕТОД ИЗВЛЕЧЕНИЯ, ФОРМАЛИЗАЦИИ И АГРЕГАЦИИ ЭКСПЕРТНЫХ ОЦЕНОК КОНКУРИРУЮЩИХ АГЕНТОВ В ГРУППЕ

Актуальность. Рассмотрена проблема извлечения, формализации и агрегации экспертных оценок при поиске наилучшего решения из множества возможных. Актуальность данной проблемы определяется разнообразием областей применения, необходимостью дополнительного анализа и групповым оцениванием в условиях неопределенности.

Цель. Цель данного исследования заключалась в повышении качества решений, принимаемых группой экспертов, за счет повышения эффективности процесса получения индивидуальных экспертных оценок и усовершенствования процесса их последующей агрегации.

Метод. Предложено решение рассматриваемой проблемы в виде комплексного метода, состоящего из индивидуального и группового оценивания.

Усовершенствован метод извлечения и формализации индивидуальных экспертных оценок. Предложенный метод основан на модификации метода анализа иерархий, включает в себя этапы абсолютного и относительного оценивания, позволяет определить компетентность эксперта путем вычисления коэффициента доверия к его мнению.

Усовершенствован метод определения групповых оценок агентов на основе суммирования индивидуальных экспертных оценок по каждому решению. Этот метод учитывает при вычислении суммарной оценки количественное преимущество агентов друг над другом и коэффициенты доверия к мнению каждого участника группы. Это позволяет считать мнение компетентных экспертов более значимым с целью повышения качества получаемого решения. 
Результаты. Проведенное экспериментальное исследование подтвердило работоспособность разработанного математического обеспечения. Разработанные методы продемонстрировали возможность выявлять и устранять неочевидные проблемы в решаемых задачах.

Выводы. Научная новизна работы заключается в том, что предложен комплексный метод извлечения, формализации и агрегации экспертных оценок в группе, который позволяет определить комплексную оценку конкурирующих агентов, а также вычислить количественное значение коэффициента доверия к мнению эксперта непосредственно в процессе получения индивидуальной оценки и в дальнейшем использовать его для принятия групповых решений.

Практическая значимость результатов работы заключается в том, что разработана информационная технология, реализующая предложенный комплексный метод, что позволило применить на практике данный метод для решения задач проведения тендеров, и проведены эксперименты.

Ключевые слова: экспертное оценивание, групповые оценки, индивидуальные оценки, компетентность экспертов, конкурирующие агенты.

\section{REFERENCES}

1. Karnyishev A. D., Ivanova E. A. Psihologiya deyatelnosti i upravleniya: ucheb. posobie. Irkutsk, IGEA, 2001, 186 p.

2. Mulen E. Kooperativnoe prinyatie resheniy: aksiomyi i modeli. Moscow, Mir, 1991, 464 p.

3. Mayers D. Sotsialnaya psihologiya. Piter, 2013, 800 p.

4. Ambrusa A., Greinerb B., Pathakc P. A. How individual preferences are aggregated in groups: An experimental study. Journal of Public Economics, 2015, Volume 129, pp. 1-13.

5. Budziński R., Becker J. Model of competence of experts in the computer decision support system. Quantitative Methods In Economics, 2013, Volume XIV, Issue 1, pp. 53-64.

6. Patel H. T. A Study on the Effectiveness of Group Activity and Group Discussion Method in English. International Journal of Research in Humanities and Social Sciences, 2014, Volume 2, Issue 1, pp. 13-15.

7. Parkes D. C., Xia L. A Complexity-of-Strategic-Behavior Comparison between Schulze's Rule and Ranked Pairs. Proceedings of the Twenty-Sixth AAAI Conference on Artificial Intelligence, 2012, pp. 1429-1435.

8. Roszkowska E. Rank ordering criteria weighting methods - a comparative overview. Optimum. Studia Ekonomiczne, 2013, No. 5 (65), pp. 14-33.

9. Saaty T. L., Vargas L. G. Models, Methods, Concepts \& Applications of the Analytic Hierarchy Process. Springer US, 2012, 346 p.

10. Nguyen H. T., Dawal S. Z. M., Nukman Y., Aoyama H., Case K. An Integrated Approach of Fuzzy Linguistic Preference Based AHP and Fuzzy COPRAS for Machine Tool Evaluation. PLOS One, 2015, No. 10 (9), 24 p.

11. Oliinyk A., Zaiko T., Subbotin S. Training Sample Reduction Based on Association Rules for Neuro-Fuzzy Networks Synthesis. Optical Memory and Neural Networks (Information Optics), 2014, Vol. 23, No. 2, pp. 89-95.

12. Oliinyk A., Subbotin S.A. The decision tree construction based on a stochastic search for the neuro-fuzzy network synthesis. Optical Memory and Neural Networks (Information Optics), 2015, Vol. 24, No. 1, pp. 18-27.

13. Subbotin S. A. The method of diagnostic model synthesis based on radial basis neural networks with the support of generalization properties. Radio Electronics. Computer Science. Control, 2016, No. 2, pp. 64-69.

14. Oliinyk A. Production rules extraction based on negative selection. Radio Electronics. Computer Science. Control, 2016, No. 1, pp. $40-49$.
15. Oliinyk A. O., Skrupsky S. Yu., Subbotin S. A. Experimental Investigation with Analyzing the Training Method Complexity of Neuro-Fuzzy Networks Based on Parallel Random Search. Automatic Control and Computer Sciences, 2015, Vol. 49, Issue 1, pp. 11-20.

16. Bodyanskiy Ye. V., Tyshchenko O. K., Boiko O. O. An evolving cascade system based on neurofuzzy nodes. Radio Electronics. Computer Science. Control, 2016, No. 2, pp. 40-45.

17. Oliinyk A. A., Subbotin S. A. Association Rules Extraction for Pattern Recognition. Pattern Recognition and Image Analysis, 2016, Vol. 26, No. 2, pp. 419-426.

18. Oliinyk A. O., Skrupsky S. Yu., Subbotin S. A. Using Parallel Random Search to Train Fuzzy Neural Networks. Automatic Control and Computer Sciences, 2014, Vol. 48, Issue 6, pp. 313323.

19. Subbotin S., Oliinyk A., Skrupsky S. Individual prediction of the hypertensive patient condition based on computational intelligence. Proceedings of the International Conference on Information and Digital Technologies, 2015, pp. 336-344.

20. Pangeran M. H., Pribad K. S. Conceptual model of analytical network process for prioritizing risk in a PPP infrastructure project. Proceedings of the First Makassar International Conference on Civil Engineering, 2010, pp. 1217-1227.

21. Jao C. S. Efficient Decision Support Systems - Practice and Challenges in Multidisciplinary Domains. InTech, 2011, 478 p.

22. Rush C., Roy R. Expert Judgement in Cost Estimating: Modelling the Reasoning Process. Concurrent Engineering, 2001, No. 9, pp. 271-284.

23. Andreychikov A. V., Andreychikova O. N. Analiz, sintez, planirovanie resheniy v ekonomike. M., Finansyi i statistika, 2012, 368 p.

24. Shrotriya S., Pandey A. Prediction of the Winner by Using a Weighted Approach of Preferential Balloting Systems on the Basis of Their Satisfied Criterions and Artifice Behavioral Complexity. 3rd International Conference on Information Security and Artificial Intelligence (ISAI 2012), Singapore, 2012, pp. 142-146.

25. Wang B., Qian Y. Determining decision makers' weights in group ranking: a granular computing method. International Journal of Machine Learning and Cybernetics, 2015, Volume 6, Issue 3, pp. 511-521.

26. Tao L. Decision Support for Contractor Selection: Incorporating consolidated Past Performance Information. University of Hong Kong, 2010, 184 p. 